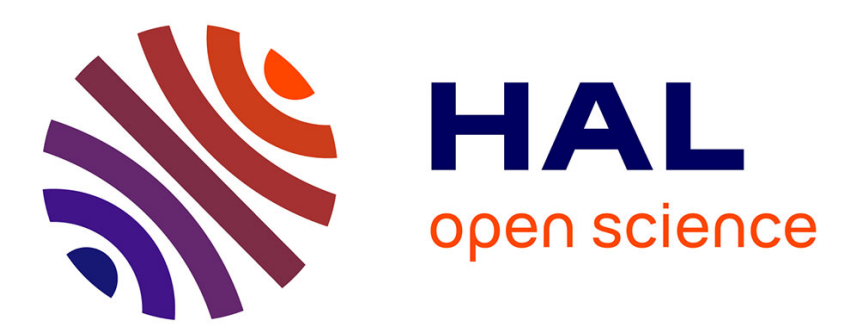

\title{
Origins and Developments of Irving Fisher's Compensated Dollar Plan
}

Jérôme de Boyer Des Roches, Rebeca Gomez Betancourt

\section{To cite this version:}

Jérôme de Boyer Des Roches, Rebeca Gomez Betancourt. Origins and Developments of Irving Fisher's Compensated Dollar Plan. History of Economic Society meeting, Jun 2012, St. Catharines, ON, Canada. hal-01500410

\section{HAL Id: hal-01500410 https://hal.science/hal-01500410}

Submitted on 3 Apr 2017

HAL is a multi-disciplinary open access archive for the deposit and dissemination of scientific research documents, whether they are published or not. The documents may come from teaching and research institutions in France or abroad, or from public or private research centers.
L'archive ouverte pluridisciplinaire HAL, est destinée au dépôt et à la diffusion de documents scientifiques de niveau recherche, publiés ou non, émanant des établissements d'enseignement et de recherche français ou étrangers, des laboratoires publics ou privés. 


\title{
History of Economic Society meeting \\ Brock University \\ June 22-26, 2012
}

\section{Origins and Developments of Irving Fisher's Compensated Dollar Plan}

\author{
Jérôme de Boyer des Roches ${ }^{1}$ \\ Paris Dauphine University - LEDa-SDFi \& PHARE, CNRS \\ Rebeca Gomez Betancourt ${ }^{2}$ \\ University of Lumière Lyon 2, Triangle, CNRS
}

\begin{abstract}
In 1911, Fisher published The Purchasing Power of Money. In chapter 13 of the first edition and in an appendix in the second section of 1913, he introduced a rule to maintain the level of prices stable, called the "compensated dollar". According to this rule, the legal definition of money is changed. In other words, the weight in gold of the dollar is modified once a month in order to impede the price changes on a basket of goods. According to Fisher, this plan will offer stability in the purchasing power of money. He sought after to find an alternative system to the price fix system under the Gold Standard. He wanted to introduce a dollar fixed in his purchasing power, but variable in its metallic weight. In this paper we will focus on Fisher's analysis on the stability of money value and his position in the debate on the compensated dollar from 1909 to 1922 . We will study the anticipations of Fisher's compensated dollar, the receptions and evolutions of Fisher's project, the gold exchange standard and the algebraic evidence. We also study the debate links to the question if the compensated dollar plan match or not with the quantity theory of money. We ends with the analysis of the gold price and elasticity of gold net supply, and we explain the relation between the Yellowbacks and the varying price of the gold reserve.
\end{abstract}

Keys words: Quantity theory, compensated dollar, prices, gold exchange standard.

Classification J.E.L.: B1, E4, E5, N11.

1 Université Paris Dauphine, LEDa-SDFi \& Phare. Place du Maréchal de Lattre de Tassigny, 75016 Paris. jdbdr@free.fr

2 Université Lumière Lyon 2. Triangle-ISH. 14 Avenue Berthelot. 69363 Lyon, Cedex 07. Rebeca.GomezBetancourt@univ-lyon2.fr 


\begin{abstract}
"My own particular interest in this project arose from my book, "The Purchasing Power of Money", and the plan developed in the last chapter for controlling the purchasing power of money". (Letter from Fisher to Kemmerer, November 2, 1911, p. 3. Series 2A. Box. 12. Correspondence. In Kemmerer Papers).

“... Professor Fisher's admirable proposal for an international currency, based upon a combination of a tabular standard and a gold-exchange standard. The main outlines of his scheme seem to deserve very careful consideration, and if he can revive general interest in such proposals, he will have done a great service to the progress of monetary reform". (Keynes 1911, P. 381).
\end{abstract}

\title{
1. Introduction
}

In chapter 13 of the first edition of The Purchasing Power of Money (1911) and in an appendix to the second edition (1913a), Irving Fisher introduced for a very first time a rule to maintain the level of prices stable, called the "compensated dollar" ${ }^{3}$. According to this rule, the weight in gold of the dollar is modified once a month in order to impede the price changes on a basket of goods. Fisher considered that this plan would offer stability in the purchasing power of the dollar. He was looking for an alternative system to the price fix system under the Gold Standard where gold dollar is fixed in weight but variable in purchasing power. He wanted to introduce a dollar fixed in his purchasing power, therefore variable in its metallic weight.

Fisher's compensated dollar plan has mainly been discussed at his time by B. M. Anderson (1913, 1919), J. M. Clark (1913), E. W. Kemmerer (1913), J. M. Keynes (1911), David Kinley (1913), Nat. C. Murray (1913), E. M. Patterson (1913), O. M. W. Sprague (1913), Frank William Taussig. (1913), Albert C. Whitaker (1913) and Knut Wicksell (1913); and more recently by Phillip Cagan (1987), David Laidler (1991), Don Patinkin (1993) and Robert Dimand $(2000,2003)$.

Our aim in this article is to put into the light the characteristics of Fisher's plan, its originality, the similarities and differences with other contemporaries proposals, specially the gold exchange standard regime, and its weaknesses. Through an archival research, we elucidate main Fisher influences to elaborate his plan, the miscomprehensions and overlook of the secondary literature and the anteriority of this reform in 1892 by a British economist, Aneurin Williams (1892a \& 1892b). We show that the idea of compensated dollar appeared very late in Fisher's writing process of the Purchasing Power of Money (1911), that the author wrongly thought that it was an adaptation of the gold-exchange standard, and did very slowly realize

\footnotetext{
${ }^{3}$ His proposition of the compensated dollar can be found in several articles and books: Fisher (1913b, 1913c, 1913d, 1913e, 1914, 1919, 1920, 1922, 1923a, 1923b, 1925, 1928, 1930a, 1934).
} 
that the consistency of his plan with his quantity theory was not obvious, furthermore that it is only in 1920 that he proposed a satisfactory explanation of the working of the plan. A solution which is not original but anachronistic.

We will focus on Fisher's analysis on the stability of money value and his position in the debate on the compensated dollar from 1911 to 1922. We will study the anticipations of Fisher's compensated dollar (section 2), the receptions and evolutions of Fisher's project (section 3), the gold exchange standard and the algebraic evidence (section 4). We also study the debate about the link between the compensated dollar plan and the quantity theory of money (section 5). We end with the analysis of the gold price elasticity of gold net supply (section 6), and we explain the relation between the "yellowbacks"4 and the varying price of the gold reserve (section 7$)^{5}$.

\section{Gold standard and stability}

Irving Fisher was preparing to write a book on monetary questions restating the quantity theory particularly in the context of the American debate, but when he read the book of his colleague E. W. Kemmerer (1907 [1903]) he wrote to him saying that now he hesitates to write a book of his own, on the same topic.

"I am delighted with its general appearance, and think that it fills a long-felt want, one which I had myself planned to try to fill. I am not sure whether there will be any need for me to write upon the subject now. If not, I shall be glad to have been saved the trouble. I hope to give a course involving this subject next year, and shall probably make use of your book as a text book." (Letter from Fisher to Kemmerer, August 14, 1907. Series 2A. Box. 14. Correspondence. In Kemmerer Papers). Our emphasis.

Then, they started an epistolary and a very close relationship including many exchanges about Fisher's draft of Purchasing Power of Money (PPM).

In 1910, three years later of the publication of Kemmerer's book, Fisher sent to his colleague his PPM manuscript. One of Kemmerer first comments was that Fisher should attach more importance to the Gold Exchange Standard (GES).

\footnotetext{
${ }^{4}$ Yellowback was the nickname given to gold certificate. These certificates were legal tender paper money issued by the Treasury, convertible in, and backed by $100 \%$ reserve of gold coins, and printed on a yellow-orange paper.

5 The ambition of this paper is not to be exhaustive on Fisher's crusade for compensated dollar. On the history of Compensated dollar proposal see Fisher (1934).
} 
"It seems to me that the recent and prospective development of the gold exchange standard is of sufficient importance to make desirable a discussion of it in this chapter". (Letter from Kemmerer to Fisher. April 4, 1910. Series 2A. Box. 12. Correspondence. In Kemmerer's Papers).

Then Fisher included the GES analysis in his draft and sent it again to Kemmerer, who answered criticizing him, underlying some inaccuracies in the passages of the PPM manuscript, devoted to the GES. Kemmerer uses as example the GES of the Philippines.

\begin{abstract}
"Your first paragraph on page 2 I think is misleading. It was not to meet objections of the kind you mention with reference to the tabular standard in the preceding paragraph that the gold exchange standard was adopted. The primary motives in its adoption were, I believe, first, the one you mention of creating a fixed par of exchange with gold standard countries; second, the motive of keeping in circulation the kind of money with which the people were familiar and which was best adapted to their needs; third, the motive of securing an inexpensive currency system, one which would support itself, and perhaps yield the Treasury some profits, and fourth, the motive of avoiding the creation of a new demand for gold. I do not think it wise to refer to India as your first illustration of the gold exchange standard. The Lindsay scheme which was proposed for India and rejected by the government was a scheme for the adoption of the gold exchange standard. The system actually put into operation was not looked upon at the time as a gold exchange standard, although it has a number of features which relate it more or less closely to the gold exchange standard, I think the Philippines is by far the best illustration." (Letter from Kemmerer to Fisher. January 6, 1911. Series 2A. Box. 12. Correspondence. In Kemmerer Papers). Our emphasis.
\end{abstract}

Finally in January 11, 1911, Fisher sent to Kemmerer a revised version of his PPM manuscript adding some explanation on GES and on his own plan to stabilize the value of the dollar. Fisher felt the need to propose a solution to the variations of the purchasing of the dollar.

"I wish it might be possible before my book really appears to have a talk with you in regard to my suggested remedy for the ills of a variable gold standard. I restrained myself from putting in any remedy until the last moment, but felt so dissatisfied with having written a book on the problem without giving any better solution than the tabular standard, that I went ever again the various solutions which had been offered, and it suddenly occurred to me that the gold exchange standard was really a half-way step to the method which I finally ventured to suggest." (Letter from Fisher to Kemmerer. January 11, 1911. Series 2A. Box. 12. Correspondence. In Kemmerer Papers). Our emphasis.

This correspondence tells us that a few months before the publication of the first edition of the PPM in 1911, the book did include neither the GES nor the dollar compensated plan. 
They are two late elements, two posterior additions to the draft of the PPM. Afterwards in 1913, Fisher also added the appendix to the second edition, on "standardizing the dollar",

\subsection{Fixed purchasing power versus fixed price of gold}

So what does the compensated dollar plan entail? The compensated dollar plan aims at stabilizing the purchasing power of the dollar - i.e. of the unit of account in which the wages and debt contracts are stipulated - by varying, suitably, the account price of gold in dollars.

According to Fisher (1913, p. 127-30) "We now have a dollar of fixed weight (25.8 grains), but varying purchasing power. Under the plan proposed, we should have a dollar of fixed purchasing power, but varying weight”. He seeks to stabilize the purchasing power of the dollar and not to stabilize the purchasing power of the gold, which, however, is used as angular stone for the monetary system.

The compensated dollar theory takes as start point the dollar as a unit of account. To explain it, we can use as example the accounting (dollar) price of an iron ton (noted $\mathrm{P}_{\mathrm{i}}$ ) and the accounting (dollar) price of an ounce of gold (noted $\mathrm{P}_{\mathrm{G}}$ ). The gold price of the iron ton (noted $\mathrm{P}_{\mathrm{i}, \mathrm{G}}$ ) being equal to the ratio of dollar price of the iron ton $\mathrm{P}_{\mathrm{i}}$ and dollar price of the ounce of gold $\mathrm{P}_{\mathrm{G}}$ :

$$
P_{i, G}=\frac{P_{i}}{P_{G}}
$$

If we note $\mathrm{T}$ and $\mathrm{G}$ for the quantities of iron exchanged and gold circulating, and we note $\mathrm{V}$ for the velocity of circulation of gold, we have the following exchange equation:

$$
P_{G} \cdot G \cdot V=P_{i} \cdot T \Leftrightarrow G \cdot V=P_{i, G} \cdot T
$$

For example, suppose that the gold price of an iron ton $\mathrm{P}_{\mathrm{i}, \mathrm{G}}$ is 0,1 ounce of gold, considering the dollar price of the ounce of gold, $\mathrm{P}_{\mathrm{i}}=20.67 \$$, the dollar price of an iron ton $\mathrm{P}_{\mathrm{i}}$ is equal to:

$$
\begin{aligned}
& P_{i}=P_{i, G} \times P_{G} \\
& P_{i}=0,1 \text { ounce of gold } / \text { iron ton } \times 20.67 \$ / \text { ounces of gold } \\
& P_{i}=2.067 \$ / \text { iron ton }
\end{aligned}
$$

The gold price of the iron ton $\mathrm{P}_{\mathrm{i}, \mathrm{G}}$ corresponds to a quantity of ounces of gold $[0,1]$, whereas its dollar price $\mathrm{P}_{\mathrm{i}}$ corresponds to a quantity of dollars [2,067]. It is this second price, in dollars, that Fisher wants to stabilize. Now, taking into account the equation of exchange,

\footnotetext{
${ }^{6}$ This appendix is actually the resumption of Fisher 1913.c article
} 
because the dollar price of gold $\mathrm{P}_{\mathrm{G}}$ is fixed, an increase in the quantity $\mathrm{G}$ of gold in circulation brings about an increase of the gold price of goods $\mathrm{P}_{\mathrm{i}, \mathrm{G}}$ as well as of their dollar price $\mathrm{P}_{\mathrm{i}}$. The value of gold-currency decrease involves the fall of the purchasing power of the dollar $1 / \mathrm{P}_{\mathrm{i}}$. As consequence, if the wages and the debt contracts are not indexed, and protected against the variations of the dollar price of goods, the "transitions periods" occur. In 1920, Fisher adds that "social injustice" and "trade cycles appear and lead to resentment and violence", "with the growth and bitterness of the I.W.W." (Fisher, 1920, pp. 61-8).

To correct this rising of the price level of goods, Fisher proposes to increase the gold value of the dollar in the same proportion that the prices in gold of the goods $\mathrm{P}$ have raised. If the dollar price level of goods increase of $1 \%$, the dollar is passed to 23,4522 grains instead of 23,22 grains. This is equivalent to decrease by $1 \%$ the dollar price of the ounce of gold: $\mathrm{P}_{\mathrm{G}}=$ $\$ 20.465$, instead of $\$ 20.67$. If one refers to the beforehand equation, this revaluation of the dollar led, ipso facto, bring back the dollar price of an iron ton $\mathrm{P}_{\mathrm{i}}$ to his former level.

\subsection{Anticipations of Fisher's compensated dollar}

When Fisher introduced his plan for the very first time in his PPM, he defined it in relation to other possible methods of correcting the variability in purchasing power of money, or avoiding its pernicious effects. More generally, his proposal took place in the wave of monetary reform proposals by quantity theorists following the crisis of bimetallism. Hence, he established closed links between his own proposal and others former proposals, like the tabular standard system [Jevons $(1875)^{7}$ and Marshall $(1886)^{8}$ ], the restoration of bimetallism, Walras's (1884) suggestion of "billion d'argent régulateur", the adoption of Polymetallism, 1886 Marshall's proposal of Symetallism and the GES. As we noticed above, according to Fisher, tabular standard and GES are the sources for his compensated dollar plan. As he wrote (1911, p. 348), "The proposal of the writer is to adopt the gold-exchange standard combined with a tabular standard". 9

The Tabular standard is a system first envisioned by Joseph Lowe (1822), then by G. Poulett Scrope (1833), both being quoted by Jevons (1875), in which monetary contracts should include an indexation clause. In case of an increase (fall) of prices, which is measured by an index number, payments would be adjusted through the proportional addition to

\footnotetext{
${ }^{7}$ Fisher quoted the 1893 edition of 1875 Jevons's book and the 1884 book.

8 Marshall's tabular standard proposal first appeared in 1885 [See Keynes (p.32) in Pigou (1925)] and was developped in 1886 (p. 9-12).

${ }^{9}$ According to Fisher his "proposal is, in mechanism, almost identical with the gold exchange device introduced by Great Britain to maintain the Indian Currency at par with gold." (Fisher 1914, p. 835)
} 
(subtraction from) the debt of a certain number of dollars in order to keep constant the value of the debt ${ }^{10}$. Its aim was not to keep the level of prices stable but to avoid the evils effects of inflation and deflation. The link between tabular standard and compensated dollar aim is obvious and well understood in the literature. It is not the same for the link between GES and compensated dollar. The GES is a system that permits to stabilize the exchange rate between a country which is neither in gold coin standard (GCS) nor in gold bullion standard (GBS) and countries which are in GCS or GBS. The effects of its functioning on the price level will be studied below.

It is worth to note that Fisher presents also two original proposals that he did not much develop in his 1911 edition.

First, he introduced the possibility to vary the Seigniorage charge and explained that the Government confining the primary money to a precious metal, for example gold, increases the charge for coinage of this metal when its supply increases in order "to keep the currency in the same relation with the volume of business, and thus to keep the level of prices stable". (Fisher 1911, p. 330). So, if the supply of gold increases in a country, the gold will tend to depreciate in value. If the aim is to keep up the value of the gold coin the State or Treasury can increase the charge for coinage in the same proportion of depreciation of the gold bullion.

Second, he studied the plan for a Convertible paper currency redeemable on demand "not in any required weight or coin of gold, but in a required purchasing power" (Fisher 1911, p. 331), looking for a supply of money which regulate itself automatically. According to Fisher (1911, p. 348) we can calculate- the quantity of Convertible paper currency needed to keep the level of prices unvarying. The big risk is the possibility for the money supply to be a subject of abuses (Fisher 1911, p. 332).

Even if Kemmerer adhesion to compensated dollar plan was doubtful, he helped Fisher to improve his plan. In a letter of January 1913, he learned to Fisher that a British economist had already propose an analogous plan:

\footnotetext{
"Recently, accidentally, I ran across a proposal very similar to yours for stabilizing the standard of value. It was 20 years ago, and was to remedy the evil of an appreciating unit of value. Like your proposal it is a combination of the idea of a variable seigniorage and the idea of the multiple standard. The article is entitled: A "Fixed value of Bullion” standard - A Proposal for Preventing General Fluctuations of Trade.
}

\footnotetext{
10 Robert Hall $(1997,2002)$ and Shiller $(2002,2011)$ establish a link between Fisher's compensated dollar and the Chilean UF (Unitad de Fomento). However, the aim of the UF is not to stabilize the peso prices but to index somme contracts and prices (houses) with the peso US dollar exchange rate.
} 
It is by Aneurin Williams in the Economic Journal, Vol. II (1892a), pp. 280-289." (From Kemmerer to Fisher, January 6, 1913. Series 2A. Box. 12. Correspondence. Letters from January 6, 1911 to March 13, 1911. In Kemmerer Papers).

See Fisher's answer:

"I think I have not answered yours of January 6th. I have (...) read Aneurin William's article, a reprint of which, with additions, was sent me by the editor of the Economic Journal, Mr. Keynes. William's proposal is almost identical with mine, although he does not provide against speculation". (From Fisher to Kemmerer, January 15, 1913. Series 2A. Box. 12. Correspondence. Letters from January 6, 1911 to March 13, 1911. In Kemmerer Papers).

In 1914, Fisher who does not hesitate to quote his colleagues underlined that his Compensated Dollar Plan had been anticipated by A. Marshall, W. Wilson and specially A. Williams and S. Newcomb to which he dedicated his PPM.

“Mr. Williams' plan, described in 1892, was first brought to my attention after the American Economic Association discussion. That of Simon Newcomb, the famous astronomer (and economist), appeared in 1879. I came upon by accident after the present article was in type. Newcomb's and William's plans are so nearly identical with mine as to leave nothing vital which I can still claim as original and unanticipated except the proviso against gold speculation. Among others who have anticipated the general idea of changing the weight of the dollar are, William C. Foster of Watertown, Mass., Henry Heaton of Atlantic, Iowa, professor Alfred Marshall (Contemporary Review, Mar. 1887, p. 371, footnote), and President Woodrow Wilson”. (Fisher 1914, p. 818).

\section{The receptions and evolutions of Fisher's project}

The chronological order of the different debates and publications is very important to reconstruct the history of the dollar compensated plan. After analyzing the correspondence between Kemmerer and Fisher during the writing process of the draft of the first edition of the PPM, we concentrate on the annual conferences of the American Economic Association (AEA) in 1911, 1912 and 1913; where Fisher developed all the arguments in favor of his Compensated dollar plan.

AEA $1911^{11}$ conference was focused on the discussion of the two contrasting positions and the US monetary debate: on the one hand we found the main defender of the quantity theory of money, Irving Fisher and on the other hand, we found the leader of the opposition;

\footnotetext{
${ }^{11}$ See D.F. Houston, E. W. Kemmerer et al. (1911).
} 
the defender of the real bills doctrine, J. Laurence Laughlin. The following year, the debate also addressed the relationships between money and prices, in particular the stability of the value of the dollar ${ }^{12}$.

In 1912, Fisher, with the support of President Taft (1909-1913), assembled economists, bankers, journalists and politicians from different states and different political stances in order to constitute ${ }^{13}$ the International Commission to investigate the causes of the high Cost of Living. He invited colleagues all round the world and his friend, Kemmerer to take part in the committee, to which Kemmerer accepted:

\begin{abstract}
"I am heartily in sympathy with your proposal for an international conference on the cost of living. The rise in the cost of living during the recent years is a phenomenon worldwide in its scope and of profound social importance. Variations in the general price level, as you have so ably shown, affect the rate of interest and also the real value of the principals of all debts expressed in terms of money". (From Kemmerer to Fisher. Nov. 8, 1911. Series 2A. Box. 12. Correspondence. Letters from January 6, 1911 to March 13, 1911. In Kemmerer Papers).
\end{abstract}

In 1913, Kemmerer and Fisher continued to discuss the problem of the rise in the cost of living while trying to find a plan to resolve it.

\begin{abstract}
"This is the third meeting of the American Economic Association in which the problem of the high cost of living has been considered. Two years ago we considered the general principles which may explain the high cost of living, and last year we considered the plan for an international conference of the high cost of living. (Fisher, 1913c 'A Remedy for the Rising Cost of Living: Standardizing the Dollar': 20)”.
\end{abstract}

1913 was undoubtedly the most prolifically year for Fisher's Plan. He published “A Compensated Dollar" (1913b), “A remedy for the Rising Cost of Living: Standardizing the Dollar" (1913c) and "Standardizing the Dollar" (1913d). An extract of Fisher (1913c) is reprinted in the appendix of the second edition of Purchasing Power of Money, with the same title.

\footnotetext{
${ }^{12}$ Fisher (1912) tooke the opportunity to publish in the Economic Journal "A More Stable Gold Standard".

13 "I enclose a list of the Committee on Foreign Affairs, indicating those who are Republicans and those who are Democrats. The Bill was introduced by Mr. Sulzer, the Chairman of this Committee, who is a Democrat. Thus far the project has fortunately escaped any partisan complexion, as both sides recognize that it is a purely scientific and humanitarian measure." (From Fisher to Kemmerer. April 17, 1912. Series 2A. Box. 12. Correspondence. Letters from Feb. 13, 1912 to October 26, 1912. In Kemmerer's Papers).
} 
We can also find the biggest confrontation and the diversity of the reactions during the debate on "Standardizing the Dollar" published in American Economic Review in $1913^{14}$. We discover several responses to the dollar compensated plan.

First we have Williard Fisher, one of the most representatives of the quantity theorists at that time, who thought that the plan is linked to the quantity theory, is logically consistent and can be implemented.

Second we have those quantity theorists like Kemmerer, David Kinley (1911), A. Whitaker, Taussig (1913), who thought that the plan is linked to the quantity theory, is logically consistent but cannot be implemented. Their main objection is that changing the legal price of gold would destabilize the exchange markets if it is not implemented at the international level, a goal that cannot be politically achieved. A second objection is that the success of the plan supposes a very high price level elasticity of the bullion supply. This is developed in section 6 below.

Third, we have a quantity theorists like O.M. Sprague, who thought that the plan is not linked to the quantity theory ${ }^{15}$, is not logically consistent and cannot be implemented. His main argument is that Fisher does not explain how and where the increase or decrease of the quantity of money necessary to make the price change does occur. This is developed in section 5 below.

Fourth, we have the anti-quantity theorists like J. Laurence Laughlin and H. Parker Willis, who thought that the plan is linked to the quantity theory and has not to be implemented. Their main argument is that the quantity theory does not make sense, that the variation of the purchasing power of the dollar is not linked to variations of the quantity of money but the cost of production of gold, and, consequently, that it is unavoidable and that changing each month the gold weight of the dollar will destabilize money.

Five, we have an anti-quantity theorists like B.M. Anderson, who thought that the plan is not linked to the quantity theory, therefore is not logically consistent and has not to be implemented. If the argument is partly analogous to Sprague's one (see section 5 below), the conclusion is close to Laughlin's one; i.e. Fisher's theory has to be rejected, whereas Sprague contests only the compensated dollar idea.

In 1914 Fisher answered publishing an article titled "Objections to a Compensated Dollar Answered". Then in 1917, he created the "Committee on the PPM in relation to the War". In

\footnotetext{
${ }^{14}$ See Murray Nat. C. \& aii (1913).

${ }^{15}$ According to Dimand (2003, p. 106), "For tactical reasons, Fisher presented his compensated dollar plan not as an application of the quantity theory of money or as a rejection of the gold standard, but as "a more Stable Gold Standard (the title of Fisher 1912) and as a corollary of the commodity theory of money, which held that the bullion content of a coin determined its value".
} 
1919 he published an article and in 1920 a book with the same title: "Stabilizing the Dollar". In 1921, he created the "Stable Money League". His campaign in favor to establish his creative compensated dollar plan continued until 1934 when he published a book on the history of this movement.

\section{Gold exchange standard and algebraic evidence}

From 1911, in his Purchasing Power of money, Fisher explained that the Gold Exchange Standard established in 1903-4 by Charles Conant (1909), Kemmerer (1904, 1905 \& 1906) and Jeremiah Jenks in Manila ${ }^{16}$ inspires his compensated dollar plan. He wrote, "the gold-exchange countries... now have a power to regulate their price level, which is not possessed by the gold standard countries themselves" (Fisher 1911, pp. 340-1). According to him, the Philippine Coinage Act -who diminished the Philippine peso price of gold- succeeded to increase the purchasing power of the Philippine peso, i.e. to diminish the price level of goods. Kemmerer had previously noticed this in an article devoted to explain the currency reform whose aim was to stabilize the dollar exchange rate of the Philippine peso, titled "The Establishment of the Gold Exchange in the Philippines". Kemmerer emphasized the question of the level of monetary prices: "An important question to be asked in connection with any currency reform is, What was its effect upon prices?". The answer is that "the general tendency of local prices appears to have been downward" (Kemmerer 1905, pp. 606-7).

Before the reform, the Philippine peso, a silver coin, circulated at par with the Mexican dollar whose value was equal to 10.32 grains of gold, i.e. was equal to 40 cents of US dollar. The reform established a theoretical Philippine gold peso, without any coinage of gold, consisting of 12.9 grains of gold, whose value was equal to 50 cents of US dollar, thus involving an increase of $25 \%$ of the dollar exchange rate of the peso. In Fisher view, such a modification of the par of exchange necessarily leads to an increase in the purchasing power of the Philippine peso. In his 1920 book, Stabilizing the Dollar (1920), he makes clear his argument: "A Mexican gold dollar weighs about half as much as ours and therefore has less purchasing power. If Mexico should adopt the same dollar that we have, no one could doubt that its purchasing power would rise about twofold, that is, the price level in Mexico would fall about half. Likewise, if we should adopt the Mexican dollar, our prices would about double" (Fisher 1920, pp. 90-1). This link between the legal peso price of gold and the purchasing power of the peso may be understood as an algebraic evidence. The previous quotation, which supposes that the purchasing power of gold is the same in Mexico and USA, claims that the

\footnotetext{
${ }^{16}$ For more details see Gomez Betancourt (2008 \& 2009).
} 
purchasing power of the peso is equal to the purchasing power of the US dollar divided by the dollar par exchange rate of the peso. Indeed, given the definition of the purchasing power of a money, here the peso:

$$
\text { Purchasing power of Peso }=\frac{\text { Purchasing power of Gold }}{\text { Peso price of Gold }}
$$

By substituting the Purchasing power of US \$ times the US \$ price of gold for the Purchasing power of Gold, we obtain:

$$
\begin{aligned}
\text { Purchasing power of Peso } & =\frac{\text { Purchasing power of US \$ x US \$ price of Gold }}{\text { Peso price of Gold }} \\
& =\text { Purchasing power of } \$: \frac{\text { Peso price of Gold }}{\text { US \$ price of Gold }}
\end{aligned}
$$

At this point, it seems obvious that it is sufficient to modify the legal peso price of gold to modify the purchasing power of the peso. Following this reasoning, and in order to explain for the first time his compensated dollar proposal, Fisher (1911) suggested that England, Germany, France, USA, and other leading gold countries could abolish free coinage and manage their exchange rate for example with Austria, in the same way that India manages its exchange rate with England or the Philippines manages its exchange rate with USA. Then, "by suitably changing the par of exchange from time to time, the whole commercial world, excepting Austria, could then keep the purchasing power of money stable, instead of allowing it to fluctuate with gold" (Fisher 1911, p. 341). Moreover, Austria could break off its isolation by maintaining the par of its money "not with a fixed weight of gold, but with such a weight of gold as should have a fixed purchasing power" (Fisher 1911, p. 342). A goal which could be reached "by buying and selling gold at these adjusted prices, selling [buying] gold bullion for gulden to contract [expand] the currency" inasmuch as "it is evident that the method of maintaining par by selling exchange on other countries, and by exchanging currency directly for some commodity, such as gold, are at bottom much the same thing" (Fisher 1911, p. 342) ${ }^{17}$. To sum up, the Philippine, the USA and the Austrian government would manage respectively: First, a gold exchange standard in order to stabilize the dollar exchange rate of the peso; second, a compensated (gold) exchange standard in order to stabilize the purchasing power of the dollar; third, a compensated gold standard in order to stabilize the purchasing power of the Austrian currency.

This explanation did not convince Fisher's contemporaneous. See for example Albert

\footnotetext{
${ }^{17}$ This is in accordance with Ricardian tradition. See de Boyer (2011).
} 
C. Whitaker's comment "Professor Fisher has suggested that the plan might be put in operation in the form of an extension of the system of the gold exchange standard. He supposes that Austria might make its home money stable - in purchasing power - by a variable seigniorage, while other countries might maintain their own money units in a fixed value relation with the Austrian unit by the new established devices of the gold-exchange system. Why not make Switzerland, or the republic of Andorra?" (Whitaker 1913, p. 35).

On his side, Kemmerer did not comment the analogy established between gold exchange standard and compensated dollar project. In fact, contrary to Fisher's belief, the analogy makes no sense. The gold exchange standard system includes a transmission mechanism that explains why a changing of the legal price of gold makes the price of goods change. The exchange rate is the transmission mechanism. It is described in 1905 Kemmerer's article. Diminishing the new Philippine peso price of gold led to issue new pesos, with higher purchasing power over gold and US dollars exchange rate, which circulated besides the old pesos (with an unchanged purchasing power over gold and US dollars exchange rate). In the market of goods, the bargaining between sellers and buyers of goods, paying either with new or old pesos, induces a falling prices for goods paid by the new pesos in comparison with those paid with old pesos. Hence the downward "general tendency of local prices" mentioned by Kemmerer.

If it is indisputable that this exchange rate transmission mechanism may be at work between a gold leading country and its colony, nevertheless it is questionable that it could exist between Andorra (or Austria) and USA. Anyway, it is missing when we consider a closed country, either Andorra or Austria, or USA. In this case, buying and selling gold, either at fixed or compensated price, does not set the money prices of all goods but only the money price of gold. Therefore, it appears that the reference to the gold exchange standard is unhelpful to understand the effect on monetary prices of changing the legal price of gold in a closed economy. Contrary to a widely held idea, gold exchange standard and compensated dollar have different features.

\section{Compensated dollar and Quantity Theory of Money}

Suppose a fall of the legal price of gold. Can we infer from Fisher's quantity theory that the price level of goods will fall? The answer of both B. M. Anderson, an anti-quantity theorist, and O. M. Sprague, a quantity theorist, is negative. For them, Fisher's monetary theory is not consistent with Fisher's plan. According to Fisher's transaction equation - in which the dollar legal price of gold does not appear - the dollar price level of goods changes when the quantity 
of money, or its velocity, change. According to the implicit definition of the purchasing power of the dollar used in Fisher compensated dollar plan, the dollar price level of goods changes when the dollar legal price of gold changes. The two equations are not equivalents. So, for Anderson, the compensated plan is consistent only if you disagree with quantity theory: "Because I am not a quantity theorist, I am disposed to believe that Professor Irving Fisher's plan of stabilizing the dollar might be feasible. (...) I believe that by putting more bullion behind the coin you can ipso facto raise the value of the dollar, and consequently lower the level of prices. But I do not see how, on the basis of the quantity theory, you could be sure of getting any definite result by Professor Fisher's plan". (Anderson 1913, p. 42) ${ }^{18}$.

Anderson defines the purchasing power of the dollar as the value of the quantity of gold bullion behind the coin, divided by the value of goods; a definition which is inherited from James L. Laughlin and which is vigorously contested by Fisher and Kemmerer ${ }^{19}$. According to this approach, there is a dichotomy between the laws determining the value of money and the laws of its circulation. Therefore, (1) the value of the bullion as well as the value of goods are given by real market forces, the production costs and utility, and are independent of circulation process; (2) the purchasing power of the dollar varies with the quantity of bullion coined in one dollar, irrespective of the quantity and velocity of money circulating.

Although Fisher rejects Laughlin's anti-quantity theory of the value of money, he did not contest that his plan could be compatible with it. On the contrary, as many scholars pointed out (Patinkin, 1993, p. 9 \& 16; Dimand, 2003, p. 106), with the aim of promoting the political success of the compensated dollar plan, Fisher claimed that the adherence to it does not infer adherence to the quantity theory: "there is nothing in the plan itself which could not be accepted equally well by those who reject the quantity theory altogether" (Fisher, 1920, p. 273). Notwithstanding Fisher's opportunism, his posture reveals a weakness of his proposal, which is also emphasized by Sprague (1913). Without a quantity mechanism which explains a falling in the general price level induced by a falling legal price of gold, quantity theorists cannot be convinced by the compensated dollar plan: "there is no exact relationship between a given seigniorage charge and changes in the level of prices; but on that account I am unable to (...) [accept] Professor Fisher's plan.” (Sprague 1913, p. 40). In order to clarify the difficulty met by Fisher, let us refer to his transaction equation.

First, let us recall that the transaction equation $\left(M . V+M^{\prime} \cdot V^{\prime}=P . Q\right)$, where $P$ is the general price level of goods, includes both current money $(\mathrm{M})$ - at the same time legal tender

\footnotetext{
${ }^{18}$ See also Anderson (1920).

${ }^{19}$ See de Boyer \& Gomez Betancourt (2011).
} 
and national bank notes ${ }^{20}$ - and bank demand deposits (M'). However, except during "transition periods", that is when the purchasing power of money is varying, M' evolution is proportionate to $\mathrm{M}^{21}$. Therefore, without forgetting credit and neglecting the functioning of the banking system, we may, at first instance, inquiry how the compensated dollar plan may stabilize the purchasing power of current money in the hypothetical economy without credit; i.e. with the simplified transaction equation: M.V = P.Q. Furthermore, we will suppose that there is no greenbacks and no national bank notes, only gold money; more precisely gold coins and gold certificates, the yellowbacks ${ }^{22}$.

Second, by substituting $\mathrm{P}_{\mathrm{G}}$. $\mathrm{G}$ for $\mathrm{M}$, we may write two equations to define:

i. The purchasing power of one ounce of gold: $\frac{P_{G}}{P}=\frac{Q}{G . V}$

ii. The purchasing power of the dollar: $\frac{1}{\mathrm{P}}=\frac{\mathrm{Q}}{\mathrm{G} \cdot \mathrm{V}} \frac{1}{\mathrm{P}_{\mathrm{G}}}$

According to the first equation (i), any change in $\mathrm{Q}, \mathrm{G}$ or $\mathrm{V}$ brings about a change of the purchasing power $\frac{\mathrm{P}_{\mathrm{G}}}{\mathrm{P}}$ of gold. According to the second equation (ii), a change of the dollar legal price of gold $\mathrm{P}_{\mathrm{G}}$ which compensates any change in $\mathrm{Q}, \mathrm{G}$ or $\mathrm{V}$, could bring about a stabilized purchasing power of the dollar $\frac{1}{\mathrm{P}}$.

For example, suppose the quantity of goods traded is multiplied by $\lambda, \mathrm{Q}_{1}=\lambda$. $\mathrm{Q}_{0}$. The equilateral hyperbole of the transaction equation $\frac{\mathrm{P}_{\mathrm{G} 0}}{\mathrm{P}} \cdot \mathrm{G} . \mathrm{V}=\mathrm{Q}$ [see below figure 1.a] shifts to the right. For given quantities of $\mathrm{G}_{0}, \mathrm{~V}$ and $\mathrm{P}_{\mathrm{G} 0}$, the equilibrium shifts from $\mathrm{E}_{0}$ to $\mathrm{E}_{1}$. According to equation (i), the price level of goods decreases $\left(\mathrm{P}_{1}<\mathrm{P}_{0}\right)$ and the purchasing power of gold increases proportionally to the increase in $\mathrm{Q}: \frac{\mathrm{P}_{\mathrm{G} 0}}{\mathrm{P}_{1}}=\frac{\mathrm{Q}_{1}}{\mathrm{G} \cdot \mathrm{V}}>\frac{\mathrm{P}_{\mathrm{G} 0}}{\mathrm{P}_{0}}=\frac{\mathrm{Q}_{0}}{\mathrm{G} \cdot \mathrm{V}}$. Likewise [see below figure 1.b], The equilateral hyperbole of the transaction equation

\footnotetext{
${ }^{20}$ See de Boyer and Gomez Betancourt (2010).

${ }^{21}$ See Gomez Betancourt (2010b).

22 Patinkin (1993, p. 16) thought erroneously that the term "yellowback "was first introduced by Fisher, "presumably to distinguished them from the famous greenbacks, which could not be redeemed for gold" (1991, p. 16). Note that the greenbacks were redeemed for gold since 1879.
} 
$\frac{1}{\mathrm{P}} \cdot \mathrm{P}_{\mathrm{G} 0} \cdot \mathrm{G} \cdot \mathrm{V}=\mathrm{Q}$ shifts to the right, showing that the purchasing power of the dollar increases proportionally to the increase in $\mathrm{Q}: \frac{1}{\mathrm{P}_{1}}=\frac{\mathrm{Q}_{1}}{\mathrm{G}_{0} \cdot \mathrm{V}} \frac{1}{\mathrm{P}_{\mathrm{G} 0}}>\frac{1}{\mathrm{P}_{0}}=\frac{\mathrm{Q}_{0}}{\mathrm{G}_{0} \cdot \mathrm{V}} \frac{1}{\mathrm{P}_{\mathrm{G} 0}}$. $\frac{P_{G}}{P}=\frac{Q}{G . V}$ $\frac{1}{\mathrm{P}}=\frac{\mathrm{Q}}{\mathrm{P}_{\mathrm{C}} \cdot \mathrm{G} \cdot \mathrm{V}}$

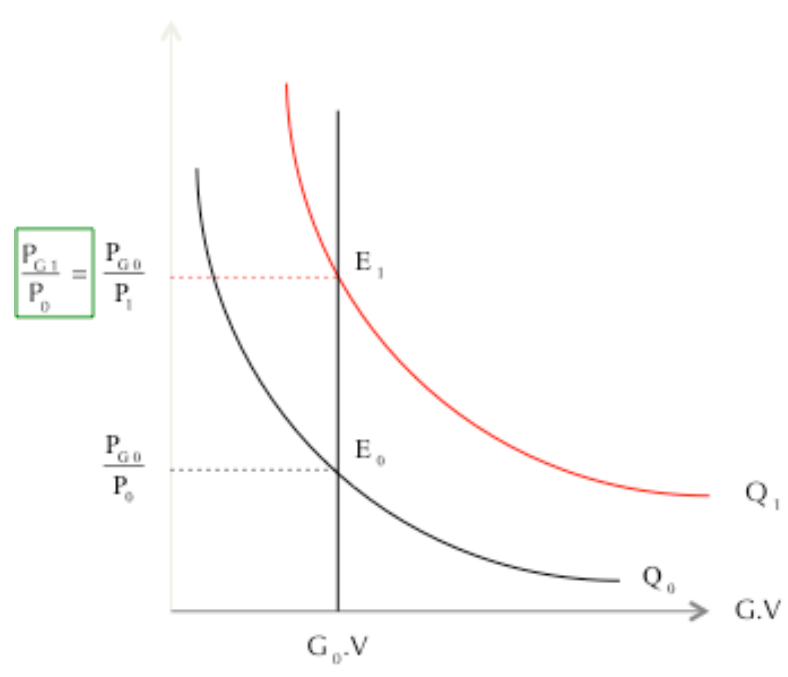

Figure 1.a

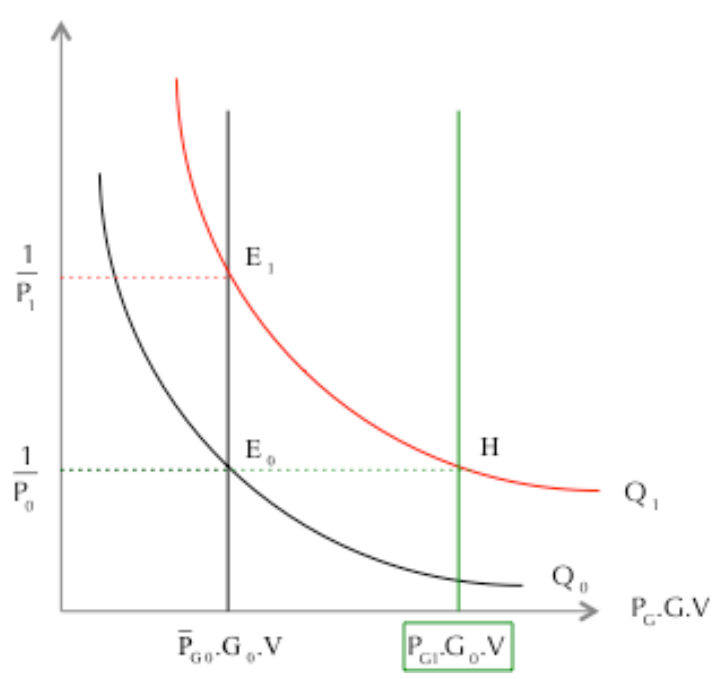

Figure 1.b

The compensated dollar plan consists to increase the legal price of gold $\mathrm{P}_{\mathrm{G}}$ - that is $\mathrm{P}_{\mathrm{G} 1}>\mathrm{P}_{\mathrm{G} 0}$ - so that the price level of goods $\mathrm{P}$ remains unchanged $-\mathrm{P}-\mathrm{P}_{\theta}$ - when the purchasing power of gold $\frac{\mathrm{P}_{G}}{\mathrm{P}}$ increases: $\frac{\mathrm{P}_{\mathrm{G} 1}}{\mathrm{P}_{0}}=\frac{\mathrm{Q}_{1}}{\mathrm{G}_{0} . \mathrm{V}}>\frac{\mathrm{P}_{\mathrm{G} 0}}{\mathrm{P}_{0}}=\frac{\mathrm{Q}_{0}}{\mathrm{G}_{0} . \mathrm{V}}$. If we look the figure 1.a., the quantity of gold $\mathrm{G}$ does not change so that the geometrical point of compensated dollar equilibrium is the same as the geometrical point of non-compensated dollar equilibrium: in $\mathrm{E}_{1}$, we have: $\frac{\mathrm{P}_{\mathrm{G} 1}}{\mathrm{P}_{0}}=\frac{\mathrm{P}_{\mathrm{G}}}{\mathrm{P}_{1}}$. On the other hand, if we look the figure 1.b, the quantity of dollars $\mathrm{P}_{\mathrm{G}} \mathrm{G}$ changes $\left[\mathrm{P}_{\mathrm{G} 1} \cdot \mathrm{G}_{0}>\mathrm{P}_{\mathrm{G} 0} \cdot \mathrm{G}_{0}\right]$ so that the geometrical point of compensated dollar equilibrium is $\mathrm{H}$, whereas the geometrical point of non-compensated dollar equilibrium is $\mathrm{E}_{1}$.

The figure 1.b shows the logic remaining behind the supposed automatic effect of a changing seigniorage charge on the price level of goods. Indeed, we are supposing here that all the outstanding stock of gold money is concerned by the change in the legal price of gold: at the equilibrium $\mathrm{H}$, the quantity of dollars $\mathrm{P}_{\mathrm{G} 0} \cdot \mathrm{G}$ is multiplied ${ }^{23}$ by $\lambda=\frac{\mathrm{P}_{\mathrm{G} 1}}{\mathrm{P}_{\mathrm{G} 0}}: \mathrm{P}_{\mathrm{G} 1} \cdot \mathrm{G}_{0}=\frac{\mathrm{P}_{\mathrm{G} 1}}{\mathrm{P}_{\mathrm{G} 0}} \mathrm{P}_{\mathrm{G} 0} \cdot \mathrm{G}_{0}$

${ }^{23} \lambda=\frac{\mathrm{P}_{\mathrm{G} 1}}{\mathrm{P}_{\mathrm{G} 0}}=\frac{\mathrm{P}_{0}}{\mathrm{P}_{1}}=\frac{\mathrm{Q}_{1}-\mathrm{Q}_{0}}{\mathrm{Q}_{0}}$. 
However, this is not the case in Fisher's plan. Fisher did neither suggest to introduce the distinction between real money and accounting money, nor to modify the accounting price of the outstanding stock of real money in circulation ${ }^{24}$. Only the coinage of new money and the issue of new yellowbacks are concerned by the proposed change in the legal price of gold. Therefore, to make sense, that means to be in accordance with quantity theory, Fisher's plan has to explain how a change of the legal price of gold could entail a proportionate change in the quantity G of gold money, either coins or yellowbacks.

\section{Price of gold and elasticity of gold net supply}

From his 1911 book, Fisher's compensated proposal plan has several essential characteristics concerning the issue of money. First, the government substitutes a token currency system for a free coinage of gold. Second, the government buys, and sells, unlimited quantity of gold bullion supplied, and demanded, at legal price, thus increasing and decreasing the quantity of currency in circulation. Third, the legal price of gold includes a seigniorage which is high enough to avoid the risk of melting the token coins in case of a rising of the legal price of gold. Fourth, in order to prevent speculation, the legal buying price of gold is lower than the selling price.

It is worthy of note that, contrary to other token currency systems established in the colonies, it is not the quantity of currency $\mathrm{M}$ which is determined by the government, but the price of gold at which he will issue and retire currency. Now, the quantity of currency issued, or withdrawn from circulation, is determined by the supply of and demand for gold bullion of private agents: the miners, the jewelers and the international gold traders. Let's put out the international gold traders whose supply and demand depend from the exchange rates and consider the miners and jewelers. Their aggregate net supply of gold bullion $\mathrm{B}^{\mathrm{s}}$ increases with the relative price between gold and goods $\frac{\mathrm{P}_{\mathrm{G}}}{\mathrm{P}}$. Given the legal price of gold $\mathrm{P}_{\mathrm{G} 0}$, a decrease of the price level of goods P means that the costs of extracting gold and to produce substitutes for gold for jewelry diminish, thus inducing an increase in the supply of gold bullion: $\mathrm{P}_{1}<\mathrm{P}_{0} \Rightarrow \mathrm{B}^{\mathrm{s}}\left(\mathrm{P}_{1}, \mathrm{P}_{\mathrm{G} 0}\right)>\mathrm{B}^{\mathrm{s}}\left(\mathrm{P}_{0}, \mathrm{P}_{\mathrm{G} 0}\right) \quad[$ see below the positive slop of the curve $\Delta \mathrm{M}\left(\mathrm{P}_{\mathrm{G} 0}\right) \equiv \mathrm{B}^{\mathrm{s}}\left(\mathrm{P}_{\mathrm{G} 0}\right)$ in fig. 2.b]. Therefore, the quantity of currency increases $\left[\mathrm{M}_{2} . \mathrm{V}>\mathrm{M}_{0} . \mathrm{V}\right.$ ] so that the price level of goods increases: $\mathrm{P}_{2}>\mathrm{P}_{1}$ [see below in fig. 2.a, the line M.V shifts on the right leading to a lowering of the purchasing power of both gold and

\footnotetext{
${ }^{24}$ This does not correspond to the Malestroict-Bodin debate (de Boyer, 2002).
} 
dollar: $\frac{1}{\mathrm{P}_{2}}<\frac{1}{\mathrm{P}_{1}}$. However, because the marginal costs of extracting gold are not constant, but increasing, this first adjustment alone does not suffice to stabilize the purchasing power of the currency: $\frac{1}{\mathrm{P}_{2}}>\frac{1}{\mathrm{P}_{0}}$. Hence Fisher's proposal for compensated dollar!

Given the price level of goods, an increase in the legal price of gold is also an incentive to extract gold and to substitute other metals for gold in jewelry, thus inducing an increase in the supply of gold: $\mathrm{P}_{\mathrm{G} 3}>\mathrm{P}_{\mathrm{G} 0} \Rightarrow \mathrm{B}^{\mathrm{s}}\left(\mathrm{P}_{1}, \mathrm{P}_{\mathrm{G} 3}\right)>\mathrm{B}^{\mathrm{s}}\left(\mathrm{P}_{1}, \mathrm{P}_{\mathrm{G} 0}\right)$ [see in fig. 2.b, the curve shifts on the right]. Again, the quantity of currency rises $\left[\mathrm{M}_{3} . \mathrm{V}>\mathrm{M}_{2} \cdot \mathrm{V}\right]$, so that the price level of goods increases: $\mathrm{P}_{3}>\mathrm{P}_{2}$ [see in fig. 2.a, the line M.V shifts on the right leading to a new lowering of the purchasing power of the currency $\left.\frac{1}{\mathrm{P}_{3}}<\frac{1}{\mathrm{P}_{2}}\right]$.

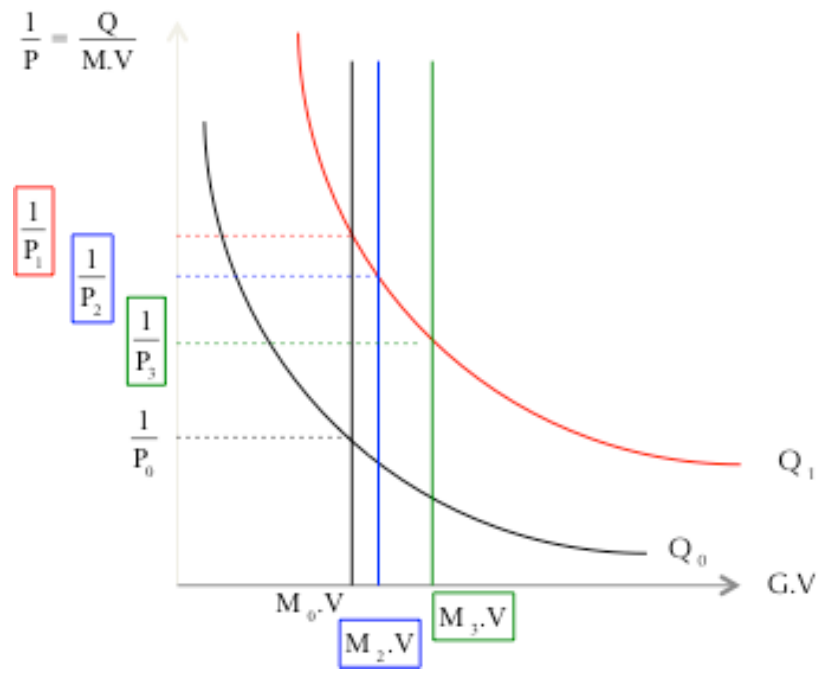

Figure 2.a

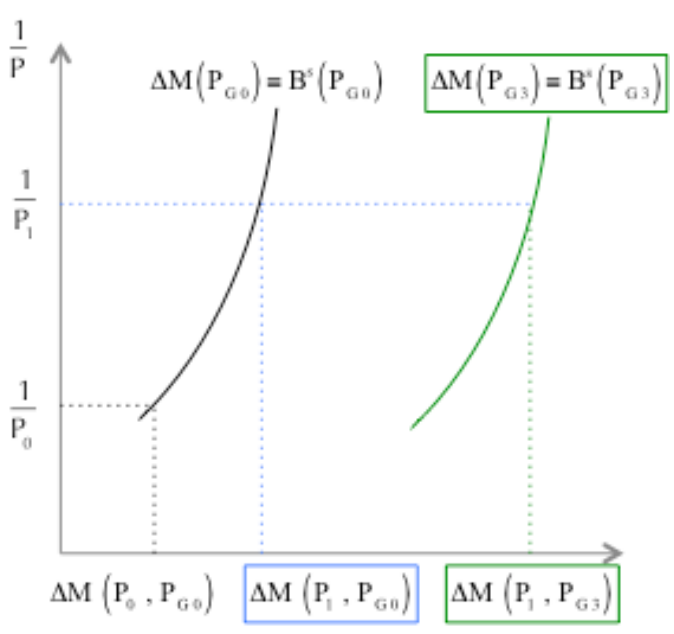

Figure 2.b

However, here again, because the marginal costs of extracting gold are not constant, but increasing, the adjustment alone cannot suffice to stabilize the purchasing power of the currency: $\frac{1}{\mathrm{P}_{3}}>\frac{1}{\mathrm{P}_{0}}$. In fact, the scale of the final effect on prices depends on the general price level elasticity of the bullion supply. Most of quantity theorists contemporaneous with Fisher, and a-priori sympathetic with his plan, thought that this elasticity is low, so they were doubtful about the possibility of stabilizing the purchasing power of dollar through this way. Furthermore, underlining the high par of exchange elasticity of gold imports and imports, they were afraid about the destabilization of exchange rates which would follow frequent changing 
legal price of gold (including speculations about them), and therefore rejected Fisher's plan as soon as 1911.

\section{Yellowbacks and varying price of the gold reserve}

Fisher adds a new, and more convincing, argument in his 1920 book, Stabilizing the dollar. We find it in the first appendix devoted to the "technical details" of his Compensated dollar plan. He supposes that currency is composed exclusively of yellowbacks, i.e. gold certificates issued by a Treasury agency. On the liability side of the balance sheet of the Treasury issuing agency, we find the outstanding amount of yellowbacks; on the asset side we find the reserve of gold bullion bought by the issuing agency. The rule would be that the yellowbacks are $100 \%$ backed by the value of the gold reserve ${ }^{25}$. Now, in case of a change of the legal price of gold, although only new gold purchases are done at the new price, the value of all the reserve is changed, thus creating a disequilibrium between this value and the outstanding amount of yellowbacks. For example, in case of an increase of legal price of gold, the value of "the reserve should exceed the [value of] certificates, the equality could be restored either by less gold or more certificates". According to Fisher, "the latter would be the simpler". Following the $100 \%$ reserve rule, "the government would issue and put into circulation the requisite number of new certificates, in making Government expenditures (...). Clearly, Fisher considers the gap between the reevaluation of the reserve in case of an increase of the legal price of gold as a profit [a loss in case of a lowering of the legal price of gold] that the government has to spend [pay/finance with taxes]: "Thus the circulation of certificates would be regulated, by issue or retirement [in case of a lowering of the legal price of gold], so as always to be equal to the number of dollars in the reserve." (Fisher 1920, p. 127).

Therefore, following the monetary $100 \%$ reserve rule involves government spending and fiscal policy. Thanks to government expenses, or savings, the $100 \%$ rule acts "promptly to stabilize the price level (...) because (...) the change in the circulation would be (...) prompt. The instant any change in the dollar's weight is made there is a change in the number of dollars of the reserve, and the volume of certificates is readjusted to this changed reserve immediately." (Fisher 1920, p. 127-30). Then, government budget policy acts as the device through which the compensating dollar policy leads to the change $\theta$ in the quantity of currency necessary for stabilizing the purchasing power of the dollar.

This outcome of the debates of the years 1911-1913 is not trivial but nonetheless

\footnotetext{
${ }^{25}$ Fisher calls "Definite-Reserve System" the situation where the gold reserve is $100 \%$ of the yellowbacks, and "Indefinite-Reserve System" the situation where the gold reserve is under $100 \%$.
} 
consistent with the quantity theory. To be effective, that is to bring about a variation of the price level of goods, a change in the legal price of gold has to cause a variation in the nominal (in dollars) quantity of money. This supposes a change either in the nominal value of all of the currency -like rising or lowering the accounting price of coined money during the Middle $\mathrm{Ages}^{26}$ - or in the quantity of currency. Fisher's proposal corresponds to the second term of the alternative (second choice/second proposition). The logic behind his proposal is that the Government sells the gold corresponding to the plus-value he makes to the Treasury issuing agency, thus increasing the quantity of yellowbacks. Of course, the yellowbacks have not to be kept out of circulation, but to be put into circulation. It is done through government spending. The overall mechanism - increase the price of gold and issue of new yellowbacks that finance government spending - seems to be more anachronistic than original.

It is not really original because Aneurin Williams expounded the same idea 28 years before than Fisher: "The Government upon lowering the mint-weight [of the sterling] will find its stock of gold more than equivalent at the new rate to its outstanding notes, and would have a surplus of gold against which to issue new notes. These as soon as put into circulation would of course increase the volume of loanable capital, and so tend to reduce the rate of discount. They would moreover, either in the hands of the Government or of some one deriving from them, constitute a fresh demand for commodities and labour, and so again tend to stimulate trade and prevent the fall of prices. In an exactly corresponding way an increase in the mintweight would tend to correct a rise of prices." (Williams 1892a, p. 281). The anachronism is that Fisher's proposal intervenes on the eve of the discovery by the Federal Reserve System of the market policy.

\section{References}

Anderson, B. M., Jr. "Standardizing the Dollar-Discussion," American Economic Review, Supplement, vol. 3 (March 1913), pp. 41-43.

Anderson, B. M., Jr. (1920), The Fallacy of the "stabilized dollar", The Chase National Bank of the City of New york, August, 1920 - in Kemmerer Archives, Box n²52, Folder 1.

Anderson, B. M., Jr. \& aii, (1919). "Stabilizing the Dollar-Discussion". American Economic Review, Vol. 9. N. 1. Supplement, Papers and Proceedings of the Thirty-First Annual Meeting of the American Economic Association, (March 1919), pp. 161-169.

de Boyer des Roches, Jérôme (2003). La pensée monétaire: histoire et analyse. Edit. Les Solos, Paris.

\footnotetext{
${ }^{26}$ See de Boyer (2002, p. 1-4).
} 
de Boyer des Roches, Jérôme (2007). "Cause and effects in the gold points mechanism: a criticism of Ricardo's criticism of Thornton". The European Journal of the History of Economic Thought, vol. 14, $\mathrm{n}^{\circ} 1$.

de Boyer des Roches, Jérôme (2009). "Bank liquidity risk from John Law (1705) to Walter Bagehot (1873)". Forthcoming in The European Journal of the History of Economic Thought. Vol.20, n ${ }^{\circ}$, August 2013.

de Boyer des Roches, Jérôme (2011). Prices, value and seigniorage in Ricardo's monetary economics, working paper for the International Conference on 'Money, Finance and Ricardo' at Meiji University in Tokyo on 28-29 March 2011, LEDa-SDFi, 12 mai 2011

de Boyer des Roches, Jérôme \& Gomez Betancourt, Rebeca (2010). "How did the US Monetary System work under the National Banking System (1863-1913)?" Paper presented at the 14th Annual Conference of the European Society for the History of Economic Thought. University of Amsterdam.

de Boyer des Roches, Jérôme \& Gomez Betancourt, Rebeca (2011). "American Quantity Theorists prior to Irving Fisher's Purchasing Power of Money". Journal of the History of Economic Thought. Coming soon.

Cagan, Phillip. "A Compensated Dollar: Better or More Likely Than Gold?” in James A. Dorn and Anna J. Schwartz, eds., The Search for Stable Money: Essays on Monetary Reform. Chicago: University of Chicago Press, 1987, pp. 261-77.

Clark, J. M. "Possible Complications of the Compensated Dollar," American Economic Review, vol. 3 (September 1913), pp. 576-88.

Conant, Charles A. (1909). "The Gold Exchange Standard in the Light of Experience". The Economic Journal, Vol. 19, N. 74. (Jun., 1909), p. 190-200.

Dimand, Robert W. (2000). "Irving Fisher and the Quantity Theory of Money: The Last Phase", Journal of the History of Economic Thought, n. 3, pp. 329-48.

Dimand, Robert W. (2003). “Competing Visions for The US Monetary System, 1907-1913: The Quest for an Elastic Currency and the Rejection of Fisher's compensated dollar rule for price stability'. Cahiers d'Economie Politique, N. 45, L'Harmattan, p. 101-121.

Fisher, Irving (1911). with Brown, Harry Gunnison. The Purchasing Power of Money. Its determination and relation to credit, interest and crises. New York, The Macmillan Company. Second edit. (1913). Reprinted in Fisher (1997), Vol. 4.

Fisher, Irving (1912). “A More Stable Gold Standard,” Economic Journal, vol. 22 (December), pp. 570-76.

Fisher, Irving (1913a). The Purchasing Power of Money: Its Determination and Relation to Credit, Interest, and Crises, rev. ed., New York: Macmillan. Reprinted, New York: Augustus M. Kelley, 1963. (Date of revised edition as given in some copies of the reprint [viz., 1922] is incorrect.) 
Fisher, Irving (1913b). “A Compensated Dollar," Quarterly Journal of Economics, vol. 27 (February), pp. 213-35. Appendixes I, II and III: pp. 385-97.

Fisher, Irving (1913c). "A Remedy for the Rising Cost of Living: Standardizing the Dollar," American Economic Review, Supplement, vol. 3 (March), pp. 20-28.

Fisher, Irving (1913d). ["Standardizing the Dollar-Discussion."] American Economic Review, Supplement, vol. 3 (March), pp. 46-51.

Fisher, Irving (1913e). Testimony before the U.S. Congress, Senate Committee on Banking and Currency. Banking and Currency, vol. 2. Hearings on S. 2639, H.R. 7837, 63 Cong. 1 Sess. Washington: Government Printing Office. (Hearings on the Federal Reserve Act.)

Fisher, Irving (1914). "Objections to a Compensated Dollar Answered," American Economic Review, vol. 4 (December), pp. 818-39.

Fisher, Irving (1919). "Stabilizing the Dollar". American Economic Review, Vol. 9. N. 1. Supplement, Papers and Proceedings of the Thirty-First Annual Meeting of the American Economic Association, (March 1919), pp. 156-160.

Fisher, Irving (1920). Stabilizing the Dollar. New York: Macmillan.

Fisher, Irving (1922). Testimony before the U.S. Congress, House of Representatives, Committee on Banking and Currency. Stabilization of the Purchasing Power of Money. Hearings on H.R. 11788, 67 Cong. 4 Sess. Washington: Government Printing Office. (Hearings on the First Goldsborough Bill.).

Fisher, Irving (1923a). Testimony before the U.S. Congress, House of Representatives, Committee on Banking and Currency. Stabilization of the Purchasing Power of Money, Part 2: Oppositions and Rebuttal. Hearings on H.R. 11788, 67 Cong. 4 Sess. Washington: Government Printing Office.

Fisher, Irving (1923b). "The Business Cycle Largely a 'Dance of the Dollar,' " Journal of the American Statistical Association, vol. 18 (December), pp. 1024-28.

Fisher, Irving (1925). "Our Unstable Dollar and the So-Called Business Cycle," Journal of the American Statistical Association, vol. 20 (June), pp. 179-202.

Fisher, Irving (1928). The Money Illusion. New York: Adelphi.

Fisher, Irving (1930a). “Compensated Dollar,” in Edwin R.A. Seligman, ed., Encyclopedia of the Social Sciences, New York: Macmillan, vol. 4, pp. 134-35.

Fisher, Irving (1934). Stable Money. New York: Adelphi.

Fisher, Irving (1997). The works of Irving Fisher. 14 volumes. Edit William Barber assisted by Robert Dimand \& Kevin Foster, consulting ed. James Tobin. London, Pickering \& Chatto.

Gomez Betancourt, Rebeca (2008). E. W. Kemmerer Money Theorist and Money Doctor. PhD Thesis. University of Paris I. Pantheon-Sorbonne. 
Gomez Betancourt, Rebeca (2009). "From the Gold Exchange Standard to the Gold Standard: The Crucial Role of E.W. Kemmerer ", Paper presented at the History of Economics Society (HES) meeting, York University, Canada.

Gomez Betancourt, Rebeca (2010a). "Edwin Walter Kemmerer's contribution to Quantity Theory of Money", European Journal of the History of Economic Thought, Volume 17, Issue 1 February 2010, pp. 115-140.

Gomez Betancourt, Rebeca (2010b). "Edwin Walter Kemmerer and the Origins of the Federal Reserve System", Journal of the History of Economic Thought, vol. 32, n4, December 2010 , pp. 445-470.

Hall Robert E. (1997). “Irving Fisher's Self-Stabilizing Money”, American Economic Review, 87(2), p. 436-438.

Hall Robert E. (2002). "Controlling the Price Level”, Contribution to Macroeconomics, 2(1), p. 1-17.

Houston, D.F., Kemmerer, E.W. \& al. (Apr., 1911). "Money and Prices: Discussion". The American Economic Review. Pp. 46-70.

Jevons, W. Stanley (1875). Money and the mechanism of exchange. H.S. King, London, Reprint, Garland, New York, 1983.

Jevons, W. Stanley (1884). Investigations in Currency and Finance, Macmillan, London . H.S. King, London - Reprint, Garland, New York, 1983 New York, Appleton and Co.

Kemmerer, Edwin Walter (1903a). Money and Credit Instruments in their Relation to General Prices. Cornell University. PhD Dissertation. Doctor of Philosophy.

Kemmerer, Edwin Walter (1904). "A gold standard for the Straits Settlements". Political Science Quarterly, Vol. 19, N. 4. p. 636-649. (Dec., 1904).

Kemmerer, Edwin Walter (1905). "The Establishment of the gold exchange standard in the Philippines". The Quarterly Journal of Economics, vol. 19, N. 4. p. 585-609. (Aug., 1905).

Kemmerer, Edwin Walter (1906). "A gold standard for the straits settlements II". Political Science Quarterly, Vol. 21, N. 4. p. 663-698 (Dec., 1906).

Kemmerer, Edwin Walter [1907] (1909). Money and Credit Instruments in their Relation to General Prices. New York, Henry Holt and Company. Nouvelle edition: New York and London: Garland, 1983.

Keynes, John Maynard (1911). "Review of Fisher, Irving, The Purchasing Power of Money (1911)", The Economic Journal, September 1911, 23. 3. Reprinted in Collected Writings of John Maynard Keynes, Vol. IX, pp. 375-81. London: Macmillan and New York, 1983.

Kinley, David. (1911). Review. Purchasing Power of Money. American Economic Review, vol. 1. N. 3 (Sep., 1911), pp. 594-596.

Kinley, David. (1913). "Objections to a Monetary Standard Based on Index Numbers," 
American Economic Review, vol. 3 (March 1913), pp. 1-19.

Laidler, David (1991). The Gold Age of the Quantity Theory. New Jersey, Princeton Univ. Press.

Laughlin, J. Laurence (1903). The Principles of Money, John Murray, London.

Lowe, Joseph (1822). The present state of England in regard to Agriculture, Trade and Finance; with a Comparison of the Prospects of England and France. Longman, Hurst, Rees, Orme, and Brown, London.

Marshall Alfred (1886). Answers from Professor Alfred Marshall to questions by the Commission on the Depreciation of Trade and Industry, reprint in Official Papers by Alfred Marshall, ed. Keynes, Macmillan, London, 1925.

Murray Nat. C. \& aii (1913). "Standardizing the Dollar-Discussion," American Economic Review, Supplement, vol. 3 (March 1913), pp. 29-51.

Patinkin, Don (1993). "Irving Fisher and His Compensated Dollar Plan". Federal Reserve Bank of Richmond. Economic Quarterly. Volume 79/3. Summer 1993.

Patterson, E. M. "Objections to a Compensated Dollar," American Economic Review, vol. 3 (December 1913), pp. 863-74.

Pigou, Arthur Cecil (1925). Memorials of Alfred Marshall, Macmillan, London.

Poulett Scrope G. (1833). An Examination of the Bank Charter Question, with an Inquiry into the Nature of a Just Standard of Value, and Suggestions for the Improvement of our Monetary System, J. Murray, London.

Shiller, Robert J. (2002). "Indexed Units of Account: Theory and Assessment of Historical Experience", I, Lefort F. \& Schmidt-Hebbel K. (eds), Indexation, Inflation and Monetary Policy, Santiago: Central Bank of Chile.

Shiller, Robert J. (2011) "Irving Fisher, Debt Deflation and Crises". Paper presented at the 2011 ASSA meeting, Denver.

Sprague, O. M. (1911). "Fisher's Purchasing Power of Money". The Quarterly Journal of Economics, Nov., 1911, vol. 26, n¹, p. 140-151.

Sprague, O. M. (1913). The American Economic Review, March 1913, vol. 3, n¹, p. 40.

Taussig, Frank William (1913). "The Plan for a Compensated dollar". The Quarterly Journal of Economics, May, 1913, vol. 27, n³, p. 401-416.

Walras Léon (1884) “Monnaie d'or avec billion régulateur". Revue de Droit International, 1er déc. 1884.

Whitaker, Albert C. (1913) "Standardizing the Dollar-Discussion," The American Economic Review, March, 1913, vol. 3, n¹, pp. 31-35. 
Williams, Aneurin (1892a). "A fixed Valued of Bullion Standard. A Proposal for Preventing General Fluctuations of Trade". Economic Journal, vol. 2, N. 6 (June, 1892), pp. 280-289.

Williams, Aneurin (1892b). "A fixed Valued of Bullion Standard". Economic Journal, vol. 2, N. 8 (December, 1892), pp. 747-749. 